\title{
Investigation of Seed Treatments for Management of Bacterial Leaf Spot of Lettuce
}

\author{
Ken Pernezny, Russell Nagata, Richard N. Raid, Janice Collins, and Amanda Carroll, University of Florida, \\ IFAS, Everglades Research and Education Center, P.O. Box 8003, Belle Glade, FL 33430
}

\begin{abstract}
Pernezny, K., Nagata, R., Raid, R. N., Collins, J., and Carroll, A. 2002. Investigation of seed treatments for management of bacterial leaf spot of lettuce. Plant Dis. 86:151-155.

Chemical seed treatments were evaluated for efficacy of disinfestation of lettuce seed that had been inoculated with Xanthomonas campestris pv. vitians. Three concentrations of each chemical were evaluated by treating seed lots for 5 or $15 \mathrm{~min}$. In addition, the effects of each seed treatment on seed germination and early plant growth were examined by observing seed germination rates. Bacteria were not detected when seed were treated with 3 or $5 \%$ hydrogen peroxide for 5 or $15 \mathrm{~min}$. Treatment of seed with $0.52 \%$ sodium hypochlorite was relatively ineffective at 5 and $15 \mathrm{~min}$. When sodium hypochlorite was used at a $1 \%$ concentration for $15 \mathrm{~min}$, the level of bacterial infestation was reduced to $2 \%$. Suspensions of copper hydroxide plus mancozeb also reduced seedborne inoculum to $\leq 2 \%$. Treatment of seed with copper hydroxide alone, benzoyl peroxide, or calcium peroxide did not reduce seed infestation levels significantly. Seed germination rates were $90 \%$ or greater for the majority of seed treatments tested in laboratory assays. Hydrogen peroxide treatments at a concentration of 5\% reduced seed germination up to $28 \%$ compared with controls. However, no significant differences in germination were observed among control treatments (noninoculated, nontreated seed and inoculated, nontreated seed) and any of the chemical seed treatments when seed were sown in a pasteurized soil mix in the greenhouse.
\end{abstract}

In the winter of 1992-93, a widespread and damaging leaf spot disease of lettuce was observed in the Everglades Agricultural Area (EAA) near Belle Glade, FL. The disease was identified as bacterial leaf spot caused by Xanthomonas campestris pv. vitians (18). This disease has been reported from other lettuce-production regions in recent years $(1,5,20,21)$. Bacterial leaf spot continues to be a disease of major concern to lettuce farmers in the EAA, due in part to the favorable conditions for disease development in the subtropical climate of southern Florida.

The occurrence of bacterial leaf spot in several countries and the observation of seed-head infections in bolting lettuce in Florida (K. Pernezny and R. N. Raid, unpublished) lead us to suggest that seedborne infections may be an important source of primary inoculum. Other researchers have investigated the use of seed treatments for management of seedborne inoculum $(5,21)$. The most effective seed treatment reported for bacterial leaf spot of

Corresponding author: Ken Pernezny

E-mail: klp@mail.ifas.ufl.edu

Florida Agricultural Experiment Station Journal Series R-08178.

Accepted for publication 8 October 2001.

Publication no. D-2001-1130-01R

(C) 2002 The American Phytopathological Society lettuce was $1 \%$ (vol/vol) sodium hypochlorite for $20 \mathrm{~min}(5)$

Peroxides have been used for some time in seed coatings $(3,9)$ to enhance seed germination, accelerate seedling emergence, and contribute to the general health of seedlings. The mechanism for these responses is thought to be the release of molecular oxygen, leading to enhanced aerobic metabolism in the embryos and young seedlings. Investigations into the concentrations and durations of exposure to peroxides were critical for optimization of the horticultural benefits of peroxides without reducing seed germination.

The bactericidal action of oxygen released from peroxides is well known (2). Dilute aqueous preparations of hydrogen peroxide have been used for many years as a topical disinfectant. Organic peroxides have been formulated for control of several species of bacteria causing local lesions on human skin (4). The possibility of direct horticultural benefits plus bactericidal activity make peroxides attractive for investigation as seed treatments for control of bacterial leaf spot of lettuce.

Treatment of seed with cupric acetate has been shown to reduce populations of $X$. campestris pv. vitians associated with seed, but not to an economically acceptable level (5). Fixed copper sprays are widely used for management of bacterial diseases of vegetables (23). Spraying tank mixes of copper and maneb or mancozeb has consistently provided better control of bacterial spot of field tomatoes than spraying copper alone $(6,10)$. However, little information is available on the efficacy of fixed coppers and copper hydroxide/mancozeb combinations as seed treatments for management of bacterial diseases.

The objectives of this study were to examine the effects of different chemicals as seed treatments, including a range of concentrations and exposure times on incidence of seed contamination with $X$. campestris pv. vitians and subsequent seed germination. Emphasis was placed on evaluation of peroxides and copper hydroxide/mancozeb combinations. A preliminary report of a portion of this work has been published (17).

\section{MATERIALS AND METHODS}

All experiments used raw (nonpelletized) lettuce seed cv. Romaine 70096 (lab studies) or Valmaine (greenhouse studies), closely related cos-type lettuces highly susceptible to bacterial leaf spot $(17,18)$. A rifampicin-resistant strain of $X$. campestris pv. vitians, L7r, was used for inoculations. Strain L7r was derived from strain L7, originally isolated from a commercial lettuce field in the EAA (18). L7r was selected as a one-step, spontaneous mutant of L7 growing on nutrient agar amended with $0.5 \%$ (wt/vol) glucose (GNA) and $100 \mu \mathrm{g}$ of rifampicin (Sigma Chemical Co., St. Louis, MO) (GNAr) per milliliter. The virulence of $\mathrm{L} 7 \mathrm{r}$ was not diminished relative to the wild-type L7 isolate, determined by pathogenicity trials in the greenhouse.

Preliminary tests were conducted to measure the amount of fluid absorbed by seed. Seed suspended in $10 \mathrm{ml}$ of sterile buffered saline $\left(3.0 \mathrm{~g}\right.$ of $\mathrm{KH}_{2} \mathrm{PO}_{4}, 7.0 \mathrm{~g}$ of $\mathrm{Na}_{2} \mathrm{HPO}_{4} \cdot 7 \mathrm{H}_{2} \mathrm{O}, 4.0 \mathrm{~g}$ of $\mathrm{NaCl}$ per liter of distilled water) (13) for $1 \mathrm{~h}$ were removed, blotted to remove excess moisture, and allowed to dry on paper towels in a laminar flow hood for $4 \mathrm{~h}$. Individual seed gained approximately $40 \%$ in weight, indicating fluid uptake into seed in an amount comparable to the infiltration method reported by Leben and Sleesman (14).

For inoculation of lettuce seed, L7r was grown on GNA plates for $72 \mathrm{~h}$ at $28^{\circ} \mathrm{C}$. Plates were flooded with sterile buffered saline and the resultant bacterial suspensions adjusted turbidimetrically to approximately $1 \times 10^{8} \mathrm{CFU} / \mathrm{ml}$. Seven grams of seed were placed in a $150-\mathrm{ml}$ beaker. Seventy-five milliliters of bacterial suspension was added to each beaker, and the 
beakers were agitated on an orbital platform shaker at $175 \mathrm{rpm}$ for $1 \mathrm{~h}$. The contents of the beakers were strained through sterile cheesecloth, and the seed dried for $24 \mathrm{~h}$ on sterile filter paper in plastic petri dishes in a laminar flow hood.

Three replicate units of 100 seed were counted, and each was placed in $10 \mathrm{ml}$ of fluid in a 50-ml beaker for seed treatment. The following chemical products were tested: sodium hypochlorite (commercial bleach) at $0.52,0.75$, and $1.04 \%$; streptomycin sulfate (Sigma Chemical Co., St. Louis, MO) at 100, 200, and $400 \mu \mathrm{g} / \mathrm{ml}$; hydrogen peroxide (Fisher Chemicals, Fair Lawn, NJ) at 1, 3, and 5\%; benzoyl peroxide (Clean and Clear Persa-Gel, $10 \%$ benzoyl peroxide gel, Johnson \& Johnson Co., Skillman, NJ) at $0.1,0.5$, and $1.0 \%$ active ingredient, suspended in sterile water; copper hydroxide (Kocide 101, Griffin L.L.C., Valdosta, GA) at 0.18, 0.24, and $0.36 \mathrm{~g} / 100 \mathrm{ml}$ of water; and copper hydroxide + mancozeb (Manzate DF, Griffin L.L.C.) at $0.18+0.14,0.24+0.18$, and $0.36+0.27 \mathrm{~g} / 100 \mathrm{ml}$ of water.

For the calcium peroxide (Alfa Aesar, Ward Hill, MA) treatment, seed were dusted in individual resealable plastic bags. Three experimental units of 100 seed were dusted in $0.25 \mathrm{~g}$ of dry calcium peroxide in individual resealable plastic bags. Seed were then placed on moistened filter paper in plastic petri dishes. A second piece of moistened filter paper was placed on top of the seed. Because of the potential for hazardous reactivity with water, treatment with calcium peroxide was carried out in a fume hood. Seed were exposed to the calcium peroxide slurry for 5 or $15 \mathrm{~min}$ and then spread on fresh, sterile filter paper to air dry. Seed were scraped onto sterile cheesecloth placed over the mouths of 50$\mathrm{ml}$ beakers and washed with a gentle stream of sterile water for approximately 1 min to remove all excess calcium peroxide from seed surfaces. Seed were dried for $2 \mathrm{~h}$ before carrying out the bacterial contamination and seed germination assays.

Seed were exposed to each concentration of each chemical for 5 and $15 \mathrm{~min}$. For all chemical treatments except calcium peroxide, excess diluent was drained off and seed were placed on sterile filter paper to dry. Two control treatments were included in these experiments. Inoculated seed treated with sterile water instead of a chemical served as a positive control. Noninoculated seed immersed in sterile buffered saline instead of inoculum and treated with sterile water was used as a negative control.

Seed from all treatments were placed on plates of GNAr and incubated at $28^{\circ} \mathrm{C}$ for 4 days. Individual seed from which typical xanthomonad colonies grew were recorded as infested, and the percent infested seed was calculated.

Another three sets of 100 seed were used to test the effect of each treatment on seed germination. After seed lots were treated as described above, they were dried on filter paper for approximately $2 \mathrm{~h}$. Each unit of 100 seed was placed on a disk of sterile black construction paper moistened with sterile distilled water, and placed on the laboratory bench (approximate temperature $23^{\circ} \mathrm{C}$ ). The dark color of the paper facilitated detection and observation of germinated seedlings. Water was added as needed to keep the paper disks moist. After 5 days, the number of seed with emerged radicles and/or epicotyls was counted and the percent germination determined.

An additional study was done in the greenhouse to evaluate the effect of selected seed treatments on germination and seedling health. Twenty-five seed, treated with each of the following, were sown in

Table 1. Analyses of variance for efficacy of chemical seed treatments for control of contamination of lettuce seed by Xanthomonas campestris pv. vitians and for the effect of these treatments on lettuce seed germination ${ }^{\mathrm{a}}$

\begin{tabular}{lrrrr}
\hline $\begin{array}{l}\text { Experiment, variable, } \\
\text { and sources of variation }\end{array}$ & df & Mean square & $\boldsymbol{F}$ value & $\boldsymbol{P}>\boldsymbol{F}$ \\
\hline $\begin{array}{rrrrr}\text { Control of contamination } \\
\quad \text { Chemical treatment }\end{array}$ & 16 & $8,492.96$ & 145.27 & 0.0001 \\
Time of exposure & 1 & $9,417.57$ & 161.00 & 0.001 \\
$\quad$ Chemical treatment $\times$ time of exposure & 14 & 126.35 & 2.16 & 0.0194 \\
$\quad$ Error & 64 & 58.46 & & \\
$\quad$ Total & 95 & & & \\
Seed germination & & & & \\
$\quad$ Chemical treatment & 16 & 203.33 & 13.05 & 0.0001 \\
Time of exposure & 1 & 39.55 & 2.54 & 0.1161 \\
Chemical treatment $\times$ time of exposure & 14 & 51.13 & 3.28 & 0.0006 \\
Error & 64 & 15.58 & & \\
$\quad$ Total & 95 & & & \\
\hline
\end{tabular}

a Treatments applied were $0.52,0.75$, and $1.00 \%$ sodium hypochlorite; 100,200 , and $400 \mu \mathrm{g} / \mathrm{m}$ streptomycin sulfate; 1,3 , and $5 \%$ hydrogen peroxide; copper hydroxide at $0.18,0.24$, and $0.36 \mathrm{~g}$ of Kocide 101 formulation per $100 \mathrm{ml}$ of water; and copper hydroxide/mancozeb (Manzate DF formulation) at $0.18+0.14,0.24+0.18$, and $0.36+0.27 \mathrm{~g}$ per $100 \mathrm{ml}$ of water. All treatments were tested at exposure times of 5 and $15 \mathrm{~min}$. For contamination studies, three replicate lots of 100 seeds were inoculated with a rifampicin-resistant strain of $X$. campestris pv. vitians and plated on glucose-nutrient agar plates containing rifampicin at $100 \mu \mathrm{g} / \mathrm{ml}$. Three additional lots of 100 seed were placed on moistened sterile paper and germination recorded after 5 days. 72-cell polystyrene transplant trays filled with Fafard Soil Mix No. 2 (Conrad Fafard, Inc., Agawan, MA): 3\% hydrogen peroxide, $1 \%$ sodium hypochlorite, $0.36 \mathrm{~g}$ copper hydroxide $+0.27 \mathrm{~g}$ mancozeb in $100 \mathrm{ml}$ of water, and calcium peroxide. Exposure time was $15 \mathrm{~min}$ for all treatments. Noninoculated, nontreated seed and inoculated, nontreated seed served as controls. Percent emergence was determined 1 week later, and an assessment of any phytotoxicity was made after 2.5 weeks.

All experiments were conducted two to three times. Results were similar for repeated trials, and data from representative experiments are shown. Means and standard errors were calculated for each treatment using the univariate procedure of the SAS (SAS Institute, Cary, NC). Data were subjected to ANOVA. Specific means comparisons of interest were made by partitioning the treatment sum of squares from the ANOVA into appropriate singledegree-of-freedom contrasts $(24,25)$.

\section{RESULTS}

Several promising seed treatments for control of $X$. campestris pv. vitians were identified in this study ( $F$ value for chemical seed treatments was significant at $P \leq$ 0.0001 , Table 1). Treatment of lettuce seed with hydrogen peroxide provided some of the best control (Fig. 1A). No bacteria were found in seed lots treated with 3 or $5 \%$ hydrogen peroxide for either 5 or 15 min. The control with hydrogen peroxide was statistically superior to that provided by sodium hypochlorite (single-degree-ofcontrast $F$ value $=179.9, P \leq 0.01$ ). To reduce levels of seed infestation to $\leq 2 \%$ with sodium hypochlorite, seed had to be treated with a $1.00 \%$ solution for $15 \mathrm{~min}$. Forty-seven percent (std error $=7.81$ ) of the seed treated with $0.52 \%$ sodium hypochlorite for $15 \mathrm{~min}$ was still infested.

Treatment of infested seed with copper hydroxide/mancozeb effectively reduced rates of infestation of $X$. campestris pv. vitians (Fig. 1A). Less than $10 \%$ infestation was observed for seed lots treated at all three rates of copper hydroxide/mancozeb, with $\leq 2 \%$ infested seed recorded at the highest rates of copper hydroxide/mancozeb applied for 5 or 15 min. In contrast, control with copper hydroxide alone was poor. Greater than $90 \%$ of seed treated with copper hydroxide remained infested. Streptomycin was efficacious against $X$. campestris pv. vitians, but only at the higher concentrations (200 or $400 \mu \mathrm{g} / \mathrm{ml}$ ) applied to seed lots for $15 \mathrm{~min}$.

Benzoyl peroxide and calcium peroxide did not eradicate the pathogen. Infestation levels were near $100 \%$ for all rates and duration of treatment for these chemicals (data not shown). Lowering the $\mathrm{pH}$ of the solvent might increase efficacy of the calcium peroxide slurry by releasing more oxygen (8). However, use of a succinic $\mathrm{acid} /$ sodium hydroxide buffer (pH 5.6) did 

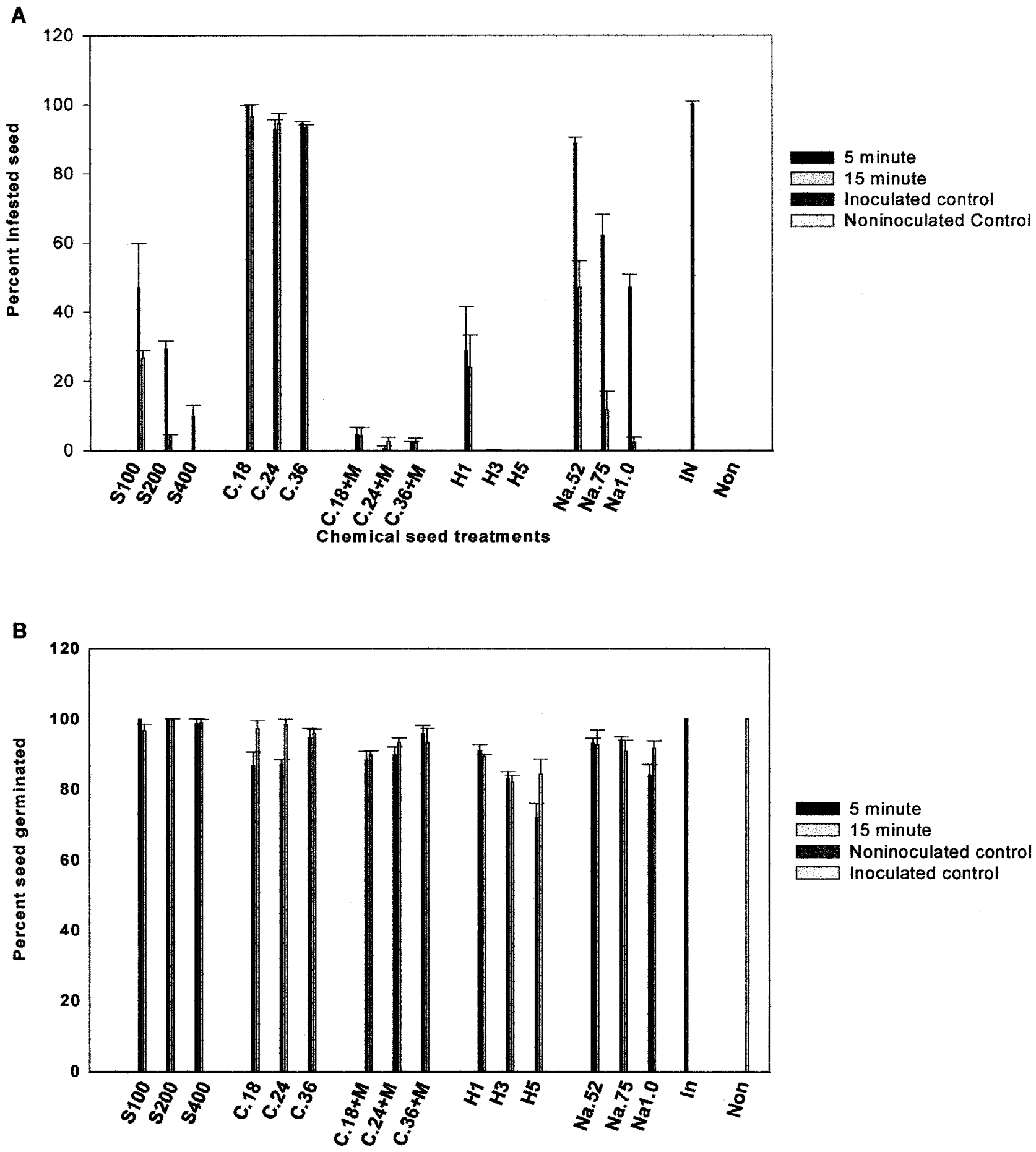

Chemical seed treatments

Fig. 1. Effect of chemical seed treatments on A, populations of Xanthomonas campestris pv. vitians, and B, germination of lettuce seed. Treatments: S100 (streptomycin sulfate, $100 \mu \mathrm{g} / \mathrm{ml}$ ); S200 (streptomycin sulfate, $200 \mu \mathrm{g} / \mathrm{ml}$ ); S400 (streptomycin sulfate, $400 \mu \mathrm{g} / \mathrm{ml}$ ); C.18 (copper hydroxide at $0.18 \mathrm{~g}$ Kocide 101 formulation $/ 100 \mathrm{ml}$ of water); C.24 (copper hydroxide at $0.24 \mathrm{~g}$ Kocide 101 formulation/ $100 \mathrm{ml}$ of water); C.36 (copper hydroxide at $0.36 \mathrm{~g}$ Kocide 101 formulation/100 ml of water); C.18+M (copper hydroxide at $0.18 \mathrm{~g}$ Kocide 101 formulation/100 ml of water + mancozeb, $0.14 \mathrm{~g} / 100 \mathrm{ml}$ of water); C.24+M (copper hydroxide at $0.24 \mathrm{~g}$ Kocide 101 formulation $/ 100 \mathrm{ml}$ of water + mancozeb, $0.18 \mathrm{~g} / 100 \mathrm{ml}$ of water); C.36+M (copper hydroxide at $0.36 \mathrm{~g}$ Kocide 101 formulation/100 $\mathrm{ml}$ of water + mancozeb, $0.27 \mathrm{~g} / 100 \mathrm{ml}$ of water); H1 (hydrogen peroxide, $1 \%$ ); H3 (hydrogen peroxide, $3 \%$ ); H5 (hydrogen peroxide, 5\%); Na.52 (sodium hypochlorite, 0.52\%); Na.75 (sodium hypochlorite, 0.75\%); Na.1.0 (sodium hypochlorite, 1.00\%); IN (inoculated control); NON (noninoculated control). Three replicate lots of 100 seed of cultivar Romaine 70096 were infested with rifampicin-resistant strain L7r by soaking in a $1 \times 10^{8} \mathrm{CFU} / \mathrm{ml}$ bacterial suspension on an orbital shaker for $1 \mathrm{~h}$. Infestation rates were determined after treatment by plating on glucosenutrient agar amended with rifampicin at $100 \mu \mathrm{g} / \mathrm{ml}$. Seed germination, based on three replicate lots of 100 seed, was measured as the percentage of radicles and/or epicotyls emerged from seed placed on moistened paper in petri dishes 5 days after treatment. The noninoculated control treatment consisted of noninfested, nontreated seed. The inoculated control treatment consisted of seed inoculated with strain L7r, but not treated with a chemical. Error bars represent one standard error of the mean. 
not improve the bactericidal performance of calcium peroxide.

Treatment of infested seed lots with streptomycin at $400 \mu \mathrm{g} / \mathrm{ml}$ reduced seed infestation to levels comparable with hydrogen peroxide and copper hydroxide/ mancozeb. The less expensive copper hydroxide/mancozeb treatments were statistically superior to the streptomycin regimens tested (single-degree-of-freedom $F$ value $=$ 46.0, $P \leq 0.01)$.

Few seed treatments adversely affected seed germination (Fig. 1B). Germination rates were $\geq 90 \%$ for 21 of the 30 seed treatments tested compared with $100 \%$ for control treatments. Four of the five lowest germination rates were for seed treated with hydrogen peroxide, with the lowest rate at $72 \%$ for $5 \%$ hydrogen peroxide for 5 min. Germination of seed treated with hydrogen peroxide was significantly less than that of seed treated with sodium hypochlorite $(83.5 \%$ versus $91 \%$, respectively, single-degree-of-freedom $F$ value $=$ $31.5, P \leq 0.01)$. Germination rates for seed treated with copper hydroxide/mancozeb, on the other hand, were comparable to sodium hypochlorite. Germination rates for seed treated with copper hydroxide/ mancozeb averaged $92 \%$ over all rates and soaking time of treatments.

No significant differences in germination rates were noted when seed treated with the different chemicals were planted in soil mix in the greenhouse (data not shown). All emerged seedlings appeared healthy and vigorous with no evidence of phytotoxicity.

\section{DISCUSSION}

Treatment of lettuce seed with solutions of aqueous 3 to $5 \%$ hydrogen peroxide or with copper hydroxide/mancozeb effectively reduced or eradicated $X$. campestris pv. vitians from heavily infested lettuce seed. In addition, the copper hydroxide/mancozeb treatment did not reduce seed germination. Small but significant reductions in germination were observed on seed lots treated with $3 \%$ hydrogen peroxide. Concentrations of hydrogen peroxide reduced rates of seed germination to unacceptable levels ( $48 \%$ or less) in preliminary tests of concentrations ranging from of 8 to $30 \%$ hydrogen peroxide (data not shown). It is interesting to note that hydrogen peroxide sold in pharmacies is a $3 \%$ solution, indicating a combination of medicinal safety and bactericidal efficacy.

Sahin and Miller (21) had good results with $0.5 \%$ sodium hypochlorite for $5 \mathrm{~min}$ soaking time, the only concentration and exposure time studied. Carisse et al. (5) tested a number of chemicals, concentrations, and soaking times and concluded that $1 \%$ sodium hypochlorite for 5 or 15 min was the most effective treatment. We also found that a $1 \%$ sodium hypochlorite concentration was necessary to reduce infestation levels below $10 \%$, but we rec- ommend a 15-min soaking time at this concentration to ensure maximum efficacy. We had more success than Carisse et al. (5) when streptomycin sulfate was used as a seed treatment at high rates $(400 \mu \mathrm{g} / \mathrm{ml})$. However, this is not likely to be recommended for use by growers because of the high cost. In addition, $400 \mu \mathrm{g} / \mathrm{ml}$ far exceeds current label rates for use as a foliar spray on several vegetable crops.

The results of this study support the report of Carisse et al. (5) that treatment of infested seed with a copper compound alone did little to reduce seedborne populations of $X$. campestris pv. vitians despite the sensitivity of strain L7 to copper when evaluated in vitro (18). Addition of mancozeb to copper hydroxide in foliar sprays $(6,10)$, dramatically improved control of bacterial spot of tomato compared with application of copper hydroxide alone. Mancozeb may increase concentrations of $\mathrm{Cu}^{2+}$ ions in contact with seed (15), resulting in greater control of $X$. campestris pv. vitians.

Survival of several bacterial pathogens through the summer in Florida and the southeast is poor $(11,16,19)$. Whether $X$. campestris pv. vitians might survive in a pathogenic or epiphytic phase (sensu Leben [12]) on weeds in Florida is unknown, but populations of $X$. campestris pv. vitians on weeds were not thought to contribute significantly to epidemics of bacterial leaf spot in California (1). Lettuce is not grown commercially in Florida from June to September. During this period, lettuce decomposes rapidly, especially in the highly organic soils of the EAA. In addition, lettuce growers in the EAA are aware of the importance of weeds as alternate hosts for Lettuce mosaic virus (7) and are assiduous in management of weeds as part of a control program for this virus disease. Therefore, seedborne inoculum is probably a primary source of infection in lettuce fields in the EAA, and seed treatment may be very important in Florida for the integrated management of bacterial leaf spot of lettuce.

Growers typically purchase lettuce seed in bulk at the beginning of the season and may hold seed for up to 6 months before planting. Little is known about the longterm effects of the seed treatments evaluated in this study on seed germination. In addition, virtually all lettuce seed sold in Florida is pelletized (i.e., coated with a Kaolin-like or diatomaceous earth matrix) before planting (22). What interactions, if any, occur between pelletization and treatment with hydrogen peroxide or other chemicals is not known. Long-term germination studies with both raw and pelletized seed are the subject of ongoing research.

\section{ACKNOWLEDGMENTS}

We thank Floyd Drummond and Ben Pernezny for their technical assistance and the Florida Fruit and Vegetable Association for financial support.
LITERATURE CITED

1. Barak, J. D., Koike, S. T., and Gilbertson, R. L. 2001. Role of crop debris and weeds in the epidemiology of bacterial leaf spot of lettuce in California. Plant Dis. 85:169-178.

2. Black, J. G. 1999. Microbiology: Principles \& Explorations. 4th ed. John Wiley \& Sons, New York.

3. Brocklehurst, P. A., and Dearman, S. 1983. Effects of calcium peroxide as a supplier of oxygen for seed germination and seedling emergence in carrot and onion. Seed Sci. Technol. 11:293-299.

4. Burkhart, C. N., Specht, K., and Neckers, D. 2000. Synergistic activity of benzoyl peroxide and erythromycin. Skin Pharmacol. Appl. Skin Physiol. 13:292-296.

5. Carisse, O., Ouimet, A., Toussaint, V., and Philion, V. 2000. Evaluation of the effect of seed treatments, bactericides, and cultivars on bacterial leaf spot of lettuce caused by Xanthomonas campestris pv. vitians. Plant Dis. 84:295-299.

6. Conover, R. A., and Gerhold, N. R. 1981. Mixtures of copper hydroxide and maneb or mancozeb for control of bacterial spot of tomato and their compatibility for control of fungus diseases. Proc. Fla. State Hortic. Soc. 94:154-156.

7. Costa, A., and Duffus, J. E. 1958. Observations on lettuce mosaic in California. Plant Dis. Rep. 52:583-586.

8. Cotton, F. A., Wilkinson, G., Murillo, C. A., and Bochmann, M. 1999. Advanced Inorganic Chemistry. 6th ed. John Wiley \& Sons, New York.

9. Duval, J. R., and Nesmith, D. S. 2000. Treatment with hydrogen peroxide and seedcoat removal or clipping improve germination of 'Genesis' triploid watermelon. HortScience 35:85-86.

10. Jones, J. B., and Jones, J. P. 1985. The effect of bactericides, tank mix time and spray schedule on bacterial leaf spot of tomato. Proc. Fla. State Hortic. Soc. 98:244-247.

11. Jones, J. B., Pohronezny, K. L., Stall, R. E., and Jones, J. P. 1986. Survival of Xanthomonas campestris pv. vesicatoria in Florida on tomato crop residue, weeds, seed, and volunteer tomato plants. Phytopathology 76:430434.

12. Leben, C. 1981. How plant-pathogenic bacteria survive. Plant Dis. 65:633-637.

13. Leben, C., Daft, G. C., and Schmitthener, A. F. 1968. Bacterial blight of soybeans: Populations levels of Pseudomonas glycinea in relation to symptom development. Phytopathology 58:1143-1146.

14. Leben, C., and Sleesman, J. P. 1981. Bacterial pathogens: Reducing seed and in vitro survival by physical treatments. Plant Dis. 65:876-878.

15. Marco, G. M., and Stall, R. E. 1983. Control of bacterial spot of pepper initiated by strains of Xanthomonas campestris pv. vesicatoria that differ in sensitivity to copper hydroxide. Plant Dis. 67:779-781.

16. McCarter, S. M., Jones, J. B., Gitaitis, R. D., and Smitley, D. R. 1983. Survival of Pseudomonas syringae pv. tomato in association with tomato seed, soil, host tissue, and epiphytic weed hosts in Georgia. Phytopathology 73:1393-1398.

17. Pernezny, K., Raid, R. N., and Collins, J. 2000. Management of bacterial leaf spot of lettuce caused by Xanthomonas campestris pv. vitians. (Abstr.) Phytopathology 90:560.

18. Pernezny, K., Raid, R. N., Stall, R. E., Hodge, N. C., and Collins, J. 1995. An outbreak of bacterial spot of lettuce in Florida caused by Xanthomonas campestris pv. vitians. Plant Dis. 79:359-360.

19. Pohronezny, K., Volin, R. B., and Stall, R. E. 
1979. An outbreak of bacterial speck on freshmarket tomatoes in south Florida. Plant Dis. Rep. 63:13-17.

20. Sahin, F. 2000. First report of bacterial spot of lettuce caused by Xanthomonas campestris pv. vitians in Turkey. Plant Dis. 84:490.

21. Sahin, F., and Miller, S. A. 1997. Identification of the bacterial leaf spot pathogen of let- tuce, Xanthomonas campestris pv. vitians in Ohio, and assessment of cultivar resistance and seed treatment. Plant Dis. 81:1143-1146.

22. Sharples, G. C. 1981. Lettuce seed coatings for enhanced seedling emergence. HortScience 16:661-662.

23. Sherf, A. F., and MacNab, A. A. 1986. Vegetable Diseases and Their Control. John Wiley
\& Sons, New York

24. Steel, R. C. D., and Torrie, J. H. 1980. Principles and Procedures of Statistics: A Biometrical Approach. McGraw-Hill, New York.

25. Swallow, W. H. 1984. Those overworked and oft-misused mean separation procedures Duncan's, LSD, etc. Plant Dis. 68:919 921. 